\title{
The educational function of drama culture and its embedded strategy in higher education
}

\author{
Wenjun Cong \\ Northeast Normal University, Changchun City, Jilin Province 130032, China; 877878075@qq.com
}

\begin{abstract}
As a comprehensive art, campus drama has an extremely rich genre, flexible form and wide audience. Drama can organically integrate ideology and morality with comprehensive quality education, and pass it on to audiences in the form of performance. In addition, it can also help contemporary college students to establish the correct world outlook, outlook on life and values, so it is an effective way to educate people in the new period. Based on the author's learning and practical experience, this work first analyzed the contribution of drama activities to the healthy development of campus culture, then summarized the current problems in carrying out campus drama activities, and finally put forward the embedded path of the educational function of the drama culture in college and universities.
\end{abstract}

Keywords: Drama culture; educational function; higher education; implementation countermeasures

\section{Introduction}

For a long time, most of the academic studies on the function of campus drama activities focus on its cultural function and educational function, but little on its ideological education function ${ }^{[1]}$. In addition, obvious problems have emerged in campus drama activities, and the driving force and conditions for sustainable development are affected by a variety of factors ${ }^{[2-3]}$. Therefore, studying the ideological and educational functions and sustainable development of campus drama activities is of great importance to strengthening and improving the ideological and political education of college students and exerting the ideological and educational functions of multiple carriers, which is a piece of work of great practical significance.

\section{The contribution of drama activities to the healthy development of campus culture}

\subsection{Enriching campus cultural life}

The comprehensive development of college students always requires the nourishment of advanced humanities and the cultivation of culture and art. College students themselves have a strong need to acquire cultural and artistic learning and to participate in cultural and artistic activities. As a specialized institution for cultural education, colleges and universities are responsible for providing college students with various types of humanities and art learning and practice, and creating cultural and artistic aesthetic needs. What is more, campus drama activities have dual characteristics of humanity and artistry. Campus drama activities can set up a cultural platform for students to learn, perform and experience drama art, meet the spiritual and cultural needs in various aspects, and enable them to develop their persona-

\footnotetext{
Copyright (C) 2019 Wenjun Cong

doi: $10.18282 /$ le.v8i2.795

This is an open-access article distributed under the terms of the Creative Commons Attribution Non-Commercial License

(http://creativecommons.org/licenses/by-nc/4.0/), which permits non-commercial use, distribution, and reproduction in any medium, provided the original work is properly cited.
} 
lity and potential. In this process, it can often cause a certain campus sensation effect and create a strong campus cultural atmosphere.

\subsection{Improving the taste and quality of campus culture}

With the gradual development of campus drama activities in colleges and universities, the taste and quality of campus culture will also be improved. The campus drama activities will allow students to truly feel the wisdom and inspiration of cultural education, and make their spirit more full, harmonious and happy. Therefore, they can realize the comprehensive, vivid, and lively development of physical and mental quality in the high-quality campus culture, and truly enhance the meaning and value of campus cultural taste. Campus drama activities play an irreplaceable role and value in the cultivation of all-round talents needed by highly civilized human society, as well as in the construction of spiritual civilization and material civilization in colleges and universities ${ }^{[4]}$.

\subsection{Expanding the carriers and approaches of ideological education in colleges and universities}

Strengthening and improving the ideological and political education of college students, striving to innovate carriers, expand channels, and increase the attractiveness and influence of ideological education are new requirements imposed on colleges and universities by the times and society. Campus drama activities are known for their popularity and universality of the activity, the autonomy and extensiveness of participation, the flexibility and openness of the form, making them become a new carrier of ideological education for college students.

\section{Problems existing in the implementation of campus drama activities}

\subsection{Lack of organization and shortage of funds}

Judging from the rules of campus drama art activities, campus drama activities require the attention of school leaders and youth league committees as well as the support of various hardware, but in fact many problems are difficult to be solved immediately. First, the school organization is weak. In terms of non-professional colleges, the campus drama art activities belong to the management and guidance of the youth league committee, which should be staffed by about one person. In the face of various music and dance activities, the youth league committee has very limited energy in organizing campus drama activities. Even if it is intentionally cultivated, it is still in a state of weakness and cannot be implemented well. Second, the shortage of funds has become an unsustainable problem in campus drama activities. A sum of money is needed to maintain a short sketch competition organized by the school, the management of a drama club, and the second class learning. In addition, the weekday teacher allowances, purchase of theater discs and books, the stage lighting during the performance of the competition, and costumes of actors all need money to maintain. In the absence of funds, the only way for campus activities to survive in the cracks is to simplify savings, which has greatly reduced college students' ability to innovate.

\subsection{Insufficient professional guidance and original motivation}

Due to the limitation of practical conditions, most colleges and universities do not offer majors related to drama performance and creation. The most relevant curriculum for drama in many schools is the "drama appreciation" general course. The low degree of students' contact reflected in it is undoubtedly unfavorable to the creation of the cultural atmosphere of campus drama. Most of the drama clubs in colleges and universities are mainly interest clubs, whose business orientation is amateur clubs, and their level is limited. In order to improve the standard of campus drama, professionals should provide guidance. Due to the lack of intervention from the school, it is difficult for students themselves to find excellent teachers to provide professional training and performance support ${ }^{[5]}$. Therefore, campus drama can only stay in a relatively rough stage of practice, which is manifested in the lack of original plays, crude performances by actors, crude stage effects and low level of audience, greatly limiting the artistic appeal of drama itself. 


\subsection{The attractiveness of performing art clubs has declined}

At present, college student associations have become a huge force in colleges and universities, but the quality has not been effectively improved while the quantity is gradually increasing, which is particularly obvious in the arts and performance associations. Many students join them with a playful attitude and are lazy in the actual rehearsal process, which greatly reduces the popularity of the performance clubs. The difficulty of hiring guidance experts and teachers has also become the main reason for the sluggishness of such associations. Although the school clearly requires that each club must be equipped with an instructor, these drama clubs still lack teachers. Therefore, some clubs invite professional teachers of the school of literature and music, or even the performance lover of the senior grade to carry on the guidance. In addition, a small number of professional drama teachers don't have enough energy to guide such clubs, the second classroom, and even the teaching of the drama class, gradually making it become a formality.

\section{Embedded path of the educational function of drama culture in colleges and universities}

\subsection{Improving the organization system to ensure the development of campus drama activities}

The development of campus drama and the accumulation of campus theater culture are inseparable from the joint efforts of teachers and students, the attention of relevant units and professionals, and the continuous input of human and material resources from the relevant departments of universities and the effective support of guarantee mechanisms. Campus drama creation and rehearsal, as a professional platform for aesthetic education practice and cultural innovation, carry out various activities such as script selection and actor recruitment. Professional instructors should provide relevant lectures to carefully guide the construction of the drama community ${ }^{[6]}$. Related departments and school league committees should pay close attention to the development of campus drama, and the youth league committee should allocate special funds to hold the whole school's "Youth Ideal" undergraduate drama show, interpreting classic plays and provincial award-winning works.

\subsection{Strengthening the construction of drama groups and building distinctive cultural brands}

For existing drama student organizations, the school should emphasize the development of university students' cultural quality as the core, take aesthetic education and artistic innovation as the guidance, and take innovation and practice as the basic requirements, so that each club has its own characteristics and cooperates with each other. During the performance of the play, members should be encouraged to communicate with and learn from each other. They should have a clear division of labor and perform their duties in every detail, such as the topic selection, creation, screening of the script, division of labor, rehearsal, and formal performances.

\subsection{Improving the level of drama activities and creating a better drama cultural environment}

Campus drama, while performing drama creative performances, is also seeking practical daily activity carriers to maintain the sustainable development of campus drama. Campus drama activities keep pace with the times and constantly integrate classics with the spirit of the times, becoming a beautiful scenery line of campus culture. Colleges and universities cultivate campus drama enthusiasts, continuously improve the audience's artistic literacy, strengthen the support for the development of campus drama, develop the exchange of drama culture between colleges and universities, and constantly expand the development space ${ }^{[7]}$. Anqing Normal University regards campus drama as an important means of quality education and humanities education, which has become an important carrier of school culture to educate and run the school. As a unique form of education, drama can give participants and viewers a direct and empathetic experience in an intuitive and effective way, and thus affect people's thoughts and emotions. It exerts political, moral, and aesthetic influences, and also effectively promotes the development of human personality and outlook on life, self-cognition, self-experience, and self-control. 


\subsection{Adhering to cultural self-confidence and strengthening the core motivation of cultural education}

Innovation is a necessary condition for the long-term development of campus drama. In drama creation, teachers and students should be greatly encouraged to draw materials from red culture, traditional culture, and local culture, so as to create original plays, and strengthen the cultivating motivation with cultural self-confidence as the core. In terms of drama practice, the enthusiasm of the participating teachers and students should be fully mobilized, and they should be encouraged to give full play to their subjective initiative, overcome the practical difficulties during rehearsals and performances, strengthen team awareness and learning ability, so that they can ignite passion for life. In terms of the drama appreciation, it should guide the audience to understand the connotative value in the drama, get the baptism of the mind and soul, and put it into study and life, then students can become conscious practitioners of the core values of socialism.

\section{Conclusion}

The development of campus drama in colleges and universities should meet the requirements of the development of the times, comprehensively improve the comprehensive literacy of college students, cultivate the innovative consciousness and creative ability of college students, and cultivate the cultural literacy and literary taste of college students. The campus drama reflects the spiritual outlook and value orientation of young people in different ages and historical stages to college students through different forms of artistic expression, and has a psychological resonance with them, reflecting the youthful theme of college students in different eras. To this end, colleges and universities should be fully aware of the problems existing in campus drama activities and seek the embedded path of the educational function of campus drama culture, which in turn promotes the sustainable development of campus drama.

\section{References}

1. Feng XQ. On Chinese modern drama education thought [J]. Journal of Aesthetic Education 2011; (2).

2. Schneider F. Chapter one introduction: Cultural governance and Chinese TV drama series [J]. Jama the Journal of the American Medical Association 2012; 113(270): 2435-2435.

3. Xu M. Chinese TV drama in a regional market: Aspiring to be a cultural actor? [J]. Telematics \& Informatics 2015; 32(1): 98-107.

4. Yang H. The realization ways of Chinese traditional culture education in Chinese course of higher colleges [J]. Journal of Hubei Correspondence University 2016; 29(6): 124-125.

5. Baughan, Lynn. Drama in further education: A study in cultural marginality [J]. University of Warwick 1990; 33(2): 165-76.

6. Zhao X. Enlightenment of Chinese traditional culture education in colleges and universities of Taiwan Province [J]. Journal of Fujian Institute of Socialism 2012; (5): 100-105.

7. Chen S. The inheritage and development of Minnan drama culture in children's drama education [J]. Journal of Liaoning Normal University (Social Sciences Edition) 2013; (6): 884-889. 